\title{
Effects of Using Siris (Albizia lebbeck) Foliage in the Diet of Fattening Lambs on Nutrient Digestibility, Blood and Rumen Parameters, Growth Performance, and Meat Quality Characteristics
}

\section{Hadi Ardeshiri}

Agricultural Sciences and Natural Resources University of Khuzestan

Morteza Chaji ( $\nabla$ mortezachaji@yahoo.com )

Agricultural Sciences and Natural Resources University of Khuzestan https://orcid.org/0000-00029336-4094

\section{Omid Khorasani}

Kharazmi Industrial School of Dezfole

\section{Research Article}

Keywords: Daily weight gain, Carcass yield, Colorimetry, Tissue, Muscle

Posted Date: January 28th, 2022

DOI: https://doi.org/10.21203/rs.3.rs-1241791/v1

License: (c) (1) This work is licensed under a Creative Commons Attribution 4.0 International License.

Read Full License 


\section{Abstract}

This study aimed to investigate the effect of substitution of Siris foliage with alfalfa forage in the diet of fattening lambs on digestibility, fermentation, and growth performance of fattening lambs. In the present experiment, 27 eight-month-old Arabi lambs $(6 \pm 3$ 1.3) with an initial weight of $28.8 \pm 1.99 \mathrm{~kg}$ were used in a completely randomized design. The effect of experimental diets on dry matter intake was not significant; however, had a significant effect on the intake of NDF, ADF, and crude protein $(P<0.05)$. The effect of experimental diets on apparent digestibility of dry matter, organic matter, NDF, ADF, and crude protein was not significant $(\mathrm{P}<0.05)$. Ammonia nitrogen concentration, $\mathrm{pH}$, and a total population of ruminal fluid protozoa and blood parameters were not affected by experimental diets. Parameters of fattening performance such as feed intake, live weight changes, feed conversion ratio, some carcass traits such as mean weight and size of carcass parts, and colorimetric indices of muscle tissue in the order of fattening lambs were not affected by experimental diets. The use of foliage of Siris in the diet of fattening lambs as a substitute with part of alfalfa had no adverse effect on the characteristics studied in the present experiment. Therefore, Siris be recommended as part of the diet of fattening lambs.

\section{Introduction}

Due to the high price of feed resources, including dietary protein sources, always many efforts have been made to use cheap and available sources to replace with common feeds in ruminant diets.

The siris plant, which scientifically known as Albizia lebbeck, is belonged to the family of Leguminosae and the subfamily of Mimosoideae. The leaves are small, green, and without thorns and hairs, and have 6 to 18 leaflets. The pods are thin, pale yellow, 15 to $30 \mathrm{~cm}$ long, and 2.5 to $5 \mathrm{~cm}$ wide, with 6 to 12 seeds (fruit) in each pod (Mozafarian 2005). The siris are widely cultivated and naturalized in some tropical and subtropical provinces of Iran, such as Khuzestan (Ahvaz, Bavi, Dezful, Shushtar, Abadan, Behbahan, and Gotvand), Bushehr, Fars, and Hormozgan (Mozafarian 2005). The siris is native to Africa and tropical Asia, northern Australia, and the tropical Americas (Balgees et al. 2009; Mozafarian 2005). In many tropical and subtropical regions of the world it is used for feeding and other purposes, also can be used in diet to reduce the costs of livestock feed (Babadi et al. 2017 and 2018; Hassan et al. 2007). However, the use of this feedstuff may limited due to the presence of some anti-nutritional substances such as tannins (El-Hawary et al 2011). Secondary metabolites of siris are include saponins, alkaloids, terpenes, and flavonoids (El-Hawary et al. 2011; Rashid et al. 2003). Annual shedding of flowers, leaves, and pods of the siris tree over 122 days period can be a source of nitrogen for livestock (Kennedy et al. 2002).

The Siris is a plant source with proper nutritional value (Babadi et al. 2017 and 2018; Hassan et al. 2007), which contains low fiber and saturated fats. The foliage of versatile trees such as Siris, Leucaena leucocephala, Morus alba and Azadirachia indica can used as a useful and inexpensive sources of protein in ruminant diets (Patra et al. 2003). Concentrations of tannins in the leaves and seeds of siris reported to be $4 \%$ and $5.3 \%$, respectively (El-Hawary et al. 2011). The main feature of tannins is binding to nutrients, especially proteins, which has an enzymatic inhibitory effect (Samtiya et al. 2020). The rapidly 
degradable (a coefficient) and potential of degradability (PD) of protein in leaves and pods of siris were more than alfalfa forage (Yousefi et al. 2016).

Replacing $5,50,75$, and $100 \%$ Siris pods or leaves instead of alfalfa in sheep diets showed that levels above $50 \%$ Siris pods in the diet reduced the in vitro digestibility of NDF (Yousefi et al. 2016). However, diets containing Siris leaves had a higher dry matter digestibility than the control diet (containing alfalfa, without replacement with alfalfa) (Yousefi et al. 2016). Hassan et al. (2007) in a study on the effect of using Siris pods and seeds in the diet of farm animals, concluded that seeds could used as a protein supplement and pods as an important source of trace elements in diets. Kennedy et al. (2002) showed that the use of $15 \%$ Siris leaves in sheep diet increases feed intake and dry matter digestibility by $52 \%$ and $67 \%$, respectively. It was reported that in goats fed bagasse supplemented with Siris leaves, the nutrient intake, and digestion were increased (Balgees et al. 2009). This study showed that Siris could be used as a source of nitrogen effectively and economically to improve the use of fibrous materials during the dry season (Balgees et al. 2009).

The results of Babadi et al. (2017) with Najdi goats showed that dry matter and protein intake, digestibility of dry matter and NDF, and rumination time $(\mathrm{kg} / \mathrm{DMI})$ were significantly higher in diets containing $50 \%$ and $75 \%$ Siris instead of alfalfa; and a diet $75 \%$ Siris, has the highest record (Babadi et al. 2017). The feeding of Siris to livestock had no significant effect on glucose and cholesterol (Babadi et al. 2017; Babadi et al. 2018). The inclusion of Siris pod in the diet reduces in vitro ammonia nitrogen concentration (Yousefi et al. 2016). Most research with Siris has been done in vitro, although there have been a few in vivo experiments that have often only measured digestibility. Therefore, considering that Siris is abundant in tropical regions of Iran and the world and there were no studies on the effects of its use in fattening livestock, in this study, the effect of its use in the diet on digestion, fermentation, growth performance, and meat color of fattening lambs was investigated.

\section{Materials And Methods}

The present experiment was performed in the educational-research station of Agricultural Sciences and Natural Resources University of Khuzestan (ASNRUKH) according to The Care and Use of Agricultural Animals in Research and Teaching guidelines (FASS 2010), and the study was approved by the ASNRUKH Animal Care Committee

Twenty-seven Arabi male lambs $6 \pm 1.3$ months old and a weight of $28.8 \pm 1.99 \mathrm{~kg}$ were selected for the present experiment. The feeding and management conditions of the selected lambs were the same, and lambs were randomly divided into three groups with no significant difference in mean initial weight. The duration of the experimental period was 75 days, including 15 days for adaptation to the diet and environment and 60 days for the sampling and data recording and collecting. The experimental diets (Table 1) were formulated according to the standard requirements of small ruminants (NRC 2007). 
Table 1

Feed ingredients and chemical composition of the experimental diets fed to lambs

Treatments

Percentage of Siris replacement with alfalfa (Siris in the whole ration)

Feed ingredients (\%DM)

Control

$50 \%$ Siris

$75 \%$ Siris

(without Siris )

Alfalfa hay

30

15

7.5

Siris

0

Wheat straw

20

15

22.5

Barley grain

20

20

20

Corn grain

3.5

20

20

Canola meal

5

3.5

3.5

Wheat bran

5

5

20

20

20

Salt

0.5

0.5

0.5

Mineral + Vitamin premix ${ }^{a}$

1

1

1

Chemical composition

Dry matter (\%)

96.52

97.00

97.08

Ash (\%)

9.50

9.04

9.04

Crude protein (\%)

13.37

13.67

13.82

NDF (\%)

54.03

54.73

55.09

ADF (\%)

24.10

23.17

22.70

ME (Mcal/Kg) ${ }^{\mathrm{b}}$

2.41

2.41

2.42

NEl (Mcal $/ \mathrm{kg})^{\mathrm{c}}$

2.54

2.48

2.39

Percentage of digestibility of organic matter (DOM) ${ }^{\mathrm{d}}$

Apparent digestibility of organic matter (IVOMAD) $)^{\mathrm{e}}$, (\%)

60.09

58.47

56.66

Short Chain Fatty Acids (SCFA) (mmol/200 mg DM) ${ }^{f}$

59.85

58.12

56.33

0.81

0.77

073 


\section{Treatments}

a Premix contained (per kg): Vitamin A, 500,000 IU/mg; vitamin $\mathrm{D}_{3}, 100000 \mathrm{IU} / \mathrm{mg}$; vitamin $\mathrm{E}, 100$ $\mathrm{mg} / \mathrm{kg} ; \mathrm{Ca}, 180 \mathrm{~g} / \mathrm{kg} ; \mathrm{P}, 60000 \mathrm{mg} / \mathrm{kg} ; \mathrm{Na}, 60000$ mg/kg; Mg, 19000 mg/kg; Zn, 3000 mg/kg; Fe, 3000 $\mathrm{mg} / \mathrm{kg} ; \mathrm{Mn}, 19000 \mathrm{mg} / \mathrm{kg} ; \mathrm{Cu}, 300 \mathrm{mg} / \mathrm{kg} ; \mathrm{Co}, 100 \mathrm{mg} / \mathrm{kg}$; Se, 1 mg/kg; l, $100 \mathrm{mg} / \mathrm{kg}$; antioxidant, 400 $\mathrm{mg} / \mathrm{kg}$; carrier, up to $1000 \mathrm{~g}$

${ }^{b} \mathrm{ME}(\mathrm{MJ} / \mathrm{Kg} \mathrm{DM})=0.04+0.1639 \mathrm{GP}+0.0079 \mathrm{CP}+0.0239 \mathrm{EE}($ Mixed feed $)$

${ }^{c} \mathrm{NEL}(\mathrm{MJ} / \mathrm{Kg} \mathrm{DM})=-1.04+0.1195 \mathrm{GP}+0.0051 \mathrm{CP}+0.0152 \mathrm{EE}($ Mixed feed $)$

${ }^{\mathrm{d}}$ DOM $(\%)=0.9042 \mathrm{GP}+0.0492 \mathrm{CP}+0.0387 \mathrm{CA}+16.49(\mathrm{n}=85 / \mathrm{r} 2=0.93)$ (Forage)

e IVOMAD $(\%)=14.88+0.8893 \mathrm{GP}+0.0448 \mathrm{CP}+0.0651$ Ash

${ }^{\mathrm{f}} \mathrm{SCFA}(\mathrm{mmol} / 200 \mathrm{mg} \mathrm{DM})=0.0222 \mathrm{GP}-0.00425$

The three experimental treatments were diets 50 and $75 \%$ replacement of Siris foliage instead of alfalfa forage in the control diet (no Siris), including 1 - control diet (no Siris), 2- diet 50\% replacement (or ration containing $15 \%$ Siris) and 3 - diet $75 \%$ replacement (or ration containing $22.5 \%$ Siris). During the experimental period, the lambs were kept in metabolic cages, fed ad libitum and had free access to drinking water.

Lamb feed intake was measured daily by weighing the feed, and the remaining amount was measured after 24 hours. In order to determine the digestibility of feed nutrients, in the last days of the experimental period (days 49-56), the method of collecting whole feces was used. The feces of lambs and the rest of their feed were collected, weighed, and recorded every 24 hours. A constant percentage of them were then stored in the cold storage for seven days. At the end of the seventh day, samples from each animal were mixed and used for subsequent measurements. Nutrient digestibility was calculated from differences in feed, residue, and feces.

For in vitro digestion and fermentation measurement, the samples were dried ( 48 hours, $60^{\circ} \mathrm{C}$ ) with an oven (Fanazma Tajhiz Gostar Co., 24 liters, Iran) and ground (2 mm mesh (2). (AOAC 2012). Chemical composition of experimental diets containing Siris, including crude protein (CP, FOSS kjeltec 2300 analyzer, Sweden; method 990.03- AOAC 2012) (Kajeldal method, Automatic Kajeltec V50, Tehran Laboratory Industries, Iran. method 990.03- AOAC 2012), ether extract (Soxhlet method, method 954.02AOAC 2012), dry matter, ash (method 942.05- AOAC 2012), acid detergent insoluble fibers (ADFom, AOAC 2012 \# 973.18) and total tannin It was measured by standard methods (AOAC 2012). Neutral detergent insoluble fibers (NDFom, corrected for ash, without alpha-amylase, and with sodium sulfite) were measured by the usual method (Van Soest et al. 1991).

In the last days of the experiment (on the 56th day), the rumen fluid of lambs was sampled via stomach tube at 3 hours after the morning feeding. The rumen $\mathrm{pH}$ ( $\mathrm{pH}$ meter, WTW, Germany) was recorded immediately to measuring ammonia nitrogen using the phenol-hypochlorite method (Spectrophotometer, 
Bio-Rad, Libra S22, Cambridge, England), the ruminal fluid was filtered with four layers of Cheesecloth and acidified with an equal proportion of 0.2M hydrochloric acid (Broderick and Kang 1980).

On the 56th day, rumen fluid of all lambs was collected via stomach tube before the morning feeding. In order to stabilize protozoa, an equal amount from ruminal fluid was mixed with $37 \%$ formaldehyde solution (diluted 50: 50 with distilled water), and protozoa were counted by the Neubauer counting chamber (Dehority 2003) using an optical microscope (NIS-Elements F 3.0, Japan).

On the 65th day, to evaluate the effect of experimental diets on blood parameters, the blood samples were taken from the jugular vein in tubes containing EDTA-Ca $10 \%$, about 3 hours after the morning meal. Blood samples were centrifuged at $3000 \mathrm{rpm}$. for 15 minutes (Hermel $236 \mathrm{HK}$, Germany), and the plasma was separated. Blood parameters were measured using an auto-analyzer (Mindray BS200, Guangzhou, China).

The lambs were weighed before the experiment and then every 15 days before morning feeding with 1416 hours of fasting, to study growth and fattening performance. Considering the amount of feed consumed and weight changes, feed conversion ratio, feed efficiency, and average daily gain and final weight were calculated (Eynipour et al. 2019).

On the last day of the experiment, the lambs were slaughtered after about 12 hours of starvation, and then differents carcass parts were weighed (Fisher and de Boer 1994).

After slaughtering the lambs, the color of the order muscle, located between ribs 12 and 13, was measured according to the $L^{*}$ (brightness), $a^{\star}$ (redness), and $b^{\star}$ (yellowness) systems using a colorimeter (Konica, model CR 400, Japan), with three replicates for each sample. The chromaticity and hue were calculated according to the colorimetric indexes (AMSA 2012).

Data were statistically analyzed using GLM procedure of SAS (version 9.4). The means were compared by Duncan's multiple range test at the error level of 0.05 for significant effects.

$Y_{i j}=\mu+T_{i}+\mathbb{V}_{i j}$

In this model, $Y_{i j}$ : the observed value, $\mu$ : the population mean, $T_{i}$ : the effect of the ith treatment, $\mathbb{}_{\mathrm{i}}$ : the residue error.

\section{Results}

\section{Nutrients intake and digestibility}

The results of the experiment showed (Table 2) that the effect of experimental treatments on the dry matter, organic matter, and protein intake were not significant $(P>0.05)$. However, it had significant effect on NDF and ADF intake $(P<0.05)$. 
Table 2

Nutrients intake $(\mathrm{g} / \mathrm{d}$ ) and digestibility $(\%)$ in lambs fed diets containing of Siris replaced with alfalfa hay

\begin{tabular}{|c|c|c|c|c|c|}
\hline \multirow[t]{2}{*}{ Item } & \multicolumn{5}{|c|}{ Treatment (Percentage of Siris replacement with alfalfa (\% in the whole ration)) } \\
\hline & Control (without Siris) & $50(15)$ & $75(22.5)$ & SEM & P-value \\
\hline \multicolumn{6}{|c|}{ Nutrients intake, $\mathrm{g} / \mathrm{d}$} \\
\hline Dry matter & 1439.89 & 1546.64 & 1428.08 & 56.787 & 0.2877 \\
\hline Organic matter & 1303.05 & 1406.97 & 1299.51 & 51.531 & 0.2679 \\
\hline NDF & $761.24^{b}$ & $940.01^{a}$ & $957.67^{a}$ & 32.290 & 0.0005 \\
\hline ADF & $360.97^{b}$ & $375.22^{a}$ & $326.02^{b}$ & 14.029 & 0.0158 \\
\hline Crude protein & 200.80 & 209.66 & 200.36 & 11.468 & 0.8152 \\
\hline \multicolumn{6}{|l|}{ Digestibility, \% } \\
\hline Dry matter & 60.83 & 59.88 & 60.86 & 4.056 & 0.4338 \\
\hline Organic matter & 63.33 & 62.76 & 64.34 & 3.595 & 0.4433 \\
\hline NDF & $52.32^{b}$ & $56.59^{\mathrm{ab}}$ & $58.89^{a}$ & 2.304 & 0.0031 \\
\hline ADF & 36.06 & 39.58 & 37.99 & 3.609 & 0.3666 \\
\hline Crude protein & 74.51 & 69.50 & 73.09 & 2.305 & 0.3311 \\
\hline
\end{tabular}

The effect of experimental diets on the apparent digestibility of dry matter, organic matter, ADF, and crude protein was not significant $(P>0.05)$. However, replacing alfalfa with Siris in the diet caused to increase in the digestibility of NDF $(P<0.05)$ and was the highest in $75 \%$ replacement treatment.

\section{Rumen fermentation parameters and protozoa population}

The results showed that the effect of experimental treatments on ammonia nitrogen concentration and ruminal $\mathrm{pH}$ was not significant $(\mathrm{P}>0.05)$, but numerically the concentration of ammonia nitrogen in diets containing Siris was lower than its concentration in the control diet (Table 3 ). 
Table 3

Rumen fermentation parameters and protozoa population $\left(\times 10^{4}\right)$ in lambs fed experimental diets containing Siris replaced with alfalfa hay

\begin{tabular}{|c|c|c|c|c|c|}
\hline \multirow[t]{2}{*}{ Item } & \multicolumn{5}{|c|}{$\begin{array}{l}\text { Treatment (Percentage of Siris replacement with alfalfa (\% in the } \\
\text { whole ration)) }\end{array}$} \\
\hline & Control (without Siris) & $50(15)$ & 75 (22.5) & SEM & P-value \\
\hline $\begin{array}{l}\text { Ammonia nitrogen, } \mathrm{mg} / \\
100 \mathrm{~mL}\end{array}$ & 19.56 & 18.09 & 18.08 & 1.714 & 0.7839 \\
\hline $\mathrm{pH}$ & 6.71 & 6.81 & 6.85 & 0.090 & 0.5613 \\
\hline \multicolumn{6}{|l|}{ protozoa population } \\
\hline Holotrichia spp. & 6.25 & 5.57 & 7.37 & 1.126 & 0.5301 \\
\hline Entidiniomorph spp. & 1.12 & 0.57 & 0.62 & 0.272 & 0.3052 \\
\hline Cellulolytic $^{a}$ & 3.25 & 3.57 & 3.87 & 0.748 & 0.8412 \\
\hline Whole Protozoa population & 10.62 & 9.71 & 11.87 & 1.0527 & 0.3637 \\
\hline \multicolumn{6}{|c|}{ a Polyplastron, Epidinium, and Eudiplodinium } \\
\hline SEM: Standard el & & & & & \\
\hline
\end{tabular}

Table 3 showed that experimental diets had no significant effect on the total population of ruminal protozoa $(P>0.05)$. Numerically, the highest populations of holotrichs, cellulites, and total were observed in $75 \%$ replacement of Siris.

\section{Blood metabolites}

Concentrations of glucose, cholesterol, urea nitrogen, LDL, HDL, triglyceride, aspartate aminotransferase, alkaline phosphatase, aspartate transferase, and blood creatine were not affected by experimental treatments $(P>0.05)$ (Table 4). 
Table 4

Concentrations of blood parameters $(\mathrm{mg} / 100 \mathrm{~mL})$ in lambs fed diets containing Siris replaced with alfalfa hay

\begin{tabular}{|c|c|c|c|c|c|}
\hline \multirow[t]{2}{*}{ Item } & \multicolumn{5}{|c|}{$\begin{array}{l}\text { Treatment (Percentage of Siris replacement with alfalfa (\% in the } \\
\text { whole ration)) }\end{array}$} \\
\hline & $\begin{array}{l}\text { Control (without } \\
\text { Siris) }\end{array}$ & $\begin{array}{l}50 \\
(15)\end{array}$ & $\begin{array}{l}75 \\
(22.5)\end{array}$ & SEM & P-value \\
\hline Glucose & 80.62 & 76.50 & 81.62 & 4.0132 & 0.6386 \\
\hline Blood urea nitrogen (BUN) & 30.87 & 35.37 & 37.00 & 2.013 & 0.1075 \\
\hline Cholesterol & 66.75 & 59.37 & 62.12 & 4.976 & 0.5790 \\
\hline Triglyceride & 16.25 & 13.60 & 16.01 & 1.597 & 0.4444 \\
\hline $\begin{array}{l}\text { Aspartate transaminase (AST or } \\
\text { SGOT) }\end{array}$ & 84.50 & 90.50 & 85.37 & 6.074 & 0.7551 \\
\hline $\begin{array}{l}\text { Alanine aminotransferase (ALT } \\
\text { or SGPT) }\end{array}$ & 23.37 & 29.00 & 25.37 & 2.355 & 0.2535 \\
\hline Alkaline phosphatase (ALP) & 38.14 & 25.00 & 23.50 & 4.950 & 0.0944 \\
\hline Creatinine & 0.71 & 0.65 & 0.69 & 0.036 & 0.4782 \\
\hline HDL & 30.00 & 23.00 & 23.86 & 3.211 & 0.2658 \\
\hline LDL & 13.14 & 12.37 & 13.62 & 0.995 & 0.4504 \\
\hline
\end{tabular}

\section{Feed consumption and growth performance}

Table 5 showed that feed consumption of different periods was not affected by experimental diets ( $P$ $>0.05$ ). Performance characteristics of lambs, such as weight changes, average daily gain, and feed conversion ratio, were not affected by experimental diets (Table 6). 
Table 5

Feed intake $(\mathrm{g} / \mathrm{d})$ of fattening lambs fed diets containing Siris replaced with alfalfa hay

\begin{tabular}{|llllll|}
\hline \multirow{2}{*}{ Item } & \multicolumn{4}{l}{ Treatment (Percentage of Siris replacement with alfalfa (\% in the whole ration)) } \\
\cline { 2 - 6 } & Control (without Siris) & $\mathbf{5 0}(\mathbf{1 5})$ & $\mathbf{7 5 ( 2 2 . 5 )}$ & SEM & P-value \\
\hline Days 0-15 & 1074.75 & 1220.27 & 1135.49 & 73.740 & 0.3909 \\
\hline Days 16-30 & 1230.31 & 1406.72 & 1292.16 & 72.652 & 0.2423 \\
\hline Days 31-45 & 1380.35 & 1527.39 & 1392.85 & 67.895 & 0.2590 \\
\hline Days 46-60 & 1468.19 & 1554.40 & 1439.49 & 55.395 & 0.3311 \\
\hline Days 0-60 & 1288.37 & 1427.19 & 1314.99 & 62.957 & 0.2760 \\
\hline SEM: Standard error of means. & & & & \\
\hline
\end{tabular}


Table 6

Growth performance of lambs fed diets containing Siris replaced with alfalfa hay

\begin{tabular}{|c|c|c|c|c|c|}
\hline \multirow[t]{2}{*}{ Item } & \multicolumn{5}{|c|}{$\begin{array}{l}\text { Treatment (Percentage of Siris replacement with alfalfa (\% in the } \\
\text { whole ration)) }\end{array}$} \\
\hline & Control (without Siris) & $50(15)$ & $75(22.5)$ & SEM & P-value \\
\hline Initial weight, kg & 28.06 & 29.92 & 28.49 & 1.998 & 0.7898 \\
\hline Weight day $15, \mathrm{~kg}$ & 30.60 & 32.30 & 30.90 & 1.987 & 0.8134 \\
\hline Weight day $30, \mathrm{~kg}$ & 33.32 & 34.82 & 33.52 & 2.038 & 0.8534 \\
\hline Weight day $45, \mathrm{~kg}$ & 35.95 & 37.05 & 35.70 & 1.950 & 0.8739 \\
\hline Final weight (Day 60), kg & 38.57 & 39.45 & 38.27 & 1.973 & 0.9091 \\
\hline $\begin{array}{l}\text { Average daily gain, } \mathrm{kg} / \text { day (Day } \\
0-15 \text { ) }\end{array}$ & 0.16 & 0.19 & 0.17 & 0.016 & 0.5487 \\
\hline $\begin{array}{l}\text { Average daily gain, } \mathrm{kg} / \text { day (Day } \\
\text { 16-30) }\end{array}$ & 0.19 & 0.16 & 0.17 & 0.019 & 0.6624 \\
\hline $\begin{array}{l}\text { Average daily gain, } \mathrm{kg} / \text { day (Day } \\
31-45 \text { ) }\end{array}$ & 0.17 & 0.16 & 0.14 & 0.018 & 0.3308 \\
\hline $\begin{array}{l}\text { Average daily gain, } \mathrm{kg} / \text { day (Day } \\
46-60 \text { ) }\end{array}$ & 0.19 & 0.15 & 0.19 & 0.015 & 0.1474 \\
\hline $\begin{array}{l}\text { Average daily gain, } \mathrm{kg} / \text { day (Day } \\
0-60 \text { ) }\end{array}$ & 0.16 & 0.17 & 0.17 & 0.017 & 0.8370 \\
\hline $\begin{array}{l}\text { Feed conversion ratio (Day 0- } \\
\text { 15) }\end{array}$ & 6.49 & 7.81 & 7.11 & 0.610 & 0.3262 \\
\hline $\begin{array}{l}\text { Feed conversion ratio (Day 16- } \\
\text { 30) }\end{array}$ & 6.94 & 8.87 & 7.59 & 0.723 & 0.1804 \\
\hline $\begin{array}{l}\text { Feed conversion ratio (Day 31- } \\
45 \text { ) }\end{array}$ & 7.81 & 7.83 & 8.78 & 0.716 & 0.5564 \\
\hline $\begin{array}{l}\text { Feed conversion ratio (Day } 46- \\
60 \text { ) }\end{array}$ & 8.57 & 10.19 & 8.62 & 0.703 & 0.2069 \\
\hline $\begin{array}{l}\text { Feed conversion ratio (Day 0- } \\
60 \text { ) }\end{array}$ & 7.47 & 9.05 & 8.14 & 0.505 & 0.1103 \\
\hline SLIVI. Stariuaru entr & & & & & \\
\hline
\end{tabular}

\section{Carcass traits}

Carcass traits were not affected by experimental treatments (Table 7). 
Table 7

Average weight and size of certain parts of lambs carcass fed diets containing Siris replaced with alfalfa hay

\begin{tabular}{|c|c|c|c|c|c|}
\hline \multirow[t]{2}{*}{ Item } & \multicolumn{5}{|c|}{$\begin{array}{l}\text { Treatment (Percentage of Siris replacement with alfalfa (\% in the } \\
\text { whole ration)) }\end{array}$} \\
\hline & $\begin{array}{l}\text { Control (without } \\
\text { Siris) }\end{array}$ & $50(15)$ & $\begin{array}{l}75 \\
(22.5)\end{array}$ & SEM & $\begin{array}{l}\mathrm{P}- \\
\text { value }\end{array}$ \\
\hline Live weight, kg & 38.70 & 40.70 & 38.53 & 1.453 & 0.5673 \\
\hline Skin, g & $4900^{a}$ & $4400^{b}$ & $4400^{b}$ & 129.099 & 0.0034 \\
\hline Leg of lamb, g & 825 & 817.50 & 862.50 & 42.180 & 0.7441 \\
\hline liver of sheep, $\mathrm{g}$ & 527.50 & 567.50 & 619.50 & 32.978 & 0.2859 \\
\hline Lung, g & 432.50 & 455 & 440 & 44.558 & 0.9374 \\
\hline Lean heart, $\mathrm{g}$ & 112.50 & 132.50 & 125 & 10.206 & 0.4704 \\
\hline Fat around the heart, $\mathrm{g}$ & 62 & 35 & 35 & 11.637 & 0.2981 \\
\hline Kidneys, g & 102.50 & 102.50 & 100 & 5.401 & 0.9326 \\
\hline Fat around the kidneys, $\mathrm{g}$ & 64 & 50 & 52 & 5.916 & 0.3305 \\
\hline Digestive system, g & 9050 & 10100 & 9100 & 429.146 & 0.2924 \\
\hline $\begin{array}{l}\text { Fat around the gastrointestinal } \\
\text { tract, } g\end{array}$ & 207.50 & 260 & 250 & 74.624 & 0.8751 \\
\hline Thigh, $g$ & 2570 & 2560 & 2750 & 94.207 & 0.3946 \\
\hline Wristband, $\mathrm{g}$ & 1527.50 & 1477.50 & $1587 / 50$ & 57.355 & 0.4874 \\
\hline Neck, g & 1410 & 1597.50 & $1707 / 50$ & 87.058 & 0.1934 \\
\hline Order and fillet, g & 1710 & 1607.50 & $1657 / 50$ & 226.743 & 0.9510 \\
\hline The spleen, $\mathrm{g}$ & 60 & 100 & 70 & 10.408 & 0.1424 \\
\hline Testicles, g & 197.50 & 222.50 & 220 & 20.716 & 0.6790 \\
\hline Flank, g & 540 & 1052.50 & 535 & 273.179 & 0.4176 \\
\hline Head, g & 2312.50 & 2287.50 & 2210 & 144.669 & 0.8776 \\
\hline Large colon, g & 207.50 & 420 & 317.50 & 135.723 & 0.5981 \\
\hline Empty colon, g & 154.50 & 240 & 199.50 & 66.396 & 0.6933 \\
\hline Small intestine full, $\mathrm{g}$ & 2550 & 2550 & 2175 & 136.168 & 0.2272 \\
\hline
\end{tabular}

SEM: Standard error of means, Means in the same row with different superscript letters are significantly different $(P<0.05)$. 


\begin{tabular}{|c|c|c|c|c|c|}
\hline \multirow[t]{2}{*}{ Item } & \multicolumn{5}{|c|}{$\begin{array}{l}\text { Treatment (Percentage of Siris replacement with alfalfa (\% in the } \\
\text { whole ration)) }\end{array}$} \\
\hline & $\begin{array}{l}\text { Control (without } \\
\text { Siris) }\end{array}$ & $50(15)$ & $\begin{array}{l}75 \\
(22.5)\end{array}$ & SEM & $\begin{array}{l}\mathrm{P}- \\
\text { value }\end{array}$ \\
\hline Full rumen, $\mathrm{g}$ & 5938.50 & 5950 & 6250 & 383.641 & 0.8202 \\
\hline Empty rumen, $\mathrm{g}$ & 1132.50 & 1395 & 800 & 314.421 & 0.4943 \\
\hline Visceral fat, g & 80 & 67.50 & 80 & 16.137 & 0.8288 \\
\hline Tail, g & 1925 & 3027.50 & 2060 & 245.938 & 0.0898 \\
\hline Horn, g & 182.50 & 285 & 335.00 & 38.106 & 0.1364 \\
\hline Gear, g & 650 & 820 & 1485 & 80.572 & 0.5122 \\
\hline Half carcass weight, $g$ & 8600 & 6922.50 & 7000 & 824.016 & 0.3878 \\
\hline
\end{tabular}

\section{Meat colour}

The results showed that experimental diets had no significant effect on the $L^{*}$ (lightness), $a^{*}$ (redness), $\mathrm{b}^{*}$ (yellowness), $\mathrm{c}^{*}$ (chroma), and Hue of the longissimus muscle of the fattening lambs (Table 8 ).

Table 8

Characterization of order muscle tissue in lambs fed diets containing Siris replaced with alfalfa hay

\begin{tabular}{|c|c|c|c|c|c|}
\hline \multirow[t]{2}{*}{ Item } & \multicolumn{5}{|c|}{ Treatment (Percentage of Siris replacement with alfalfa (\% in the whole ration)) } \\
\hline & Control (without Siris) & $50(15)$ & $75(22.5)$ & SEM & P-value \\
\hline$L^{*}$ & 27.27 & 27.10 & 25.20 & 0.655 & 0.1877 \\
\hline$A^{*}$ & 8.37 & 8.54 & 7.39 & 0.469 & 0.3120 \\
\hline$B^{\star}$ & 2.71 & 2.99 & 2.82 & 0.327 & 0.8342 \\
\hline Choroma $^{\mathrm{a}}$ & 8.80 & 9.05 & 7.92 & 0.520 & 0.3879 \\
\hline$H u e^{b}$ & 1.52 & 1.52 & 1.52 & 0.004 & 0.4635 \\
\hline \multicolumn{6}{|c|}{$L^{\star}$ : lightness; $a^{\star}$ : redness; $b^{\star}$ : yellowness; } \\
\hline \multicolumn{6}{|c|}{ a Chroma: chromaticity $\left(A^{\star 2}+B^{\star 2}\right)^{1 / 2}$. } \\
\hline \multicolumn{6}{|c|}{$\mathrm{b}$ Hue $=$ arc tangent $\mathrm{B} / \mathrm{A} \times 57.29$. } \\
\hline
\end{tabular}




\section{Discussion}

\section{Nutrients intake and digestibility}

The experimental treatments had significant effect on NDF and ADF intake, which the higher NDF intake in diets containing Siris may be related to the higher NDF content of these diets (Table 1), and the higher NDF of Siris in compared to alfalfa (55.59 vs. 50.90) (Babadi et al. 2017). According to the results of the present experiment, when substituting different amounts $(0.0,50$, and $75 \%)$ of Siris instead of alfalfa in the diet of Najdi goats, the percentage of NDF and ADF and their intake from diets containing Siris, were higher than control. In addition, the diet containing 75\% Siris had the highest intake and digestion (Babadi et al. 2018). Compared to the control diet (no Siris and contain 100\% alfalfa), and a diet containing 50\% siris, replacement of $75 \%$ Siris instead of alfalfa in the diet of Najdi goats had the highest nutrients intake, and dry matter digestibility (Babadi et al. 2018).

Agrees with the results of the present experiment, in comparison to the control diet (no Siris), in the Najdi goats fed 50 and $75 \%$ Siris instead of alfalfa, dry matter, and NDF digestibility increased, and a diet containing 75\% replacement had the highest dry matter and NDF digestibility (Babadi et al. 2018). Contrary to the results of the present experiment, when substituting $25,50,75$, and $100 \%$ Siris leaves instead of alfalfa in diets of sheep, in vitro dry matter digestibility was significantly increased (Yousefi et al. 2016). However, agreed with the results of the present experiment, the in vitro digestibility of NDF was not affected by the experimental treatments, which may be due to the use of leaves in their experiments compared to the complete branch or foliage (leaves, pods, and seeds) in the present experiment (Yousefi et al. 2014). On the other hand, replacing $25,50,75$, and $100 \%$ Siris flowers in diets of sheep instead of alfalfa, the in vitro digestibility of dry matter and NDF significantly increased (Yousefi et al. 2016). Agrees with the results of the present experiment, 50 and 75\% replacement of the pods of Siris containing seeds instead of alfalfa forage, there was no difference in in vitro dry matter digestibility of diets (Yousefi et al. 2016). The substitution of 50 and $100 \%$ Subabel (Siris family) instead of alfalfa in the diets of cattle and buffaloes had no significant effect on the in vitro digestibility of dry matter, NDF, and ADF (Shahriari et al. 1396). However, in comparison to the control (without Siris), up to $50 \%$ replacement resulted in numerically increased digestibility of these nutrients and decreased them when $100 \%$ of the replacement (Shahriari et al. 2017). Feeding oak fruit kernels (such as Siris containing tannins) to fattening goat kids did not affect the digestibility of dry matter, organic matter, ADF, and crude protein of experimental diets (Hoseinpour-mohammadabadi and Chaji 2019), which was agreed with the results of the present experiment. The reason for increasing the digestibility of nutrients, especially NDF, by using Siris in the diets, may be related to the lower ADF and the higher ME and protein of Siris (Table 1, Babadi et al. 2017 and 2018), and the higher digestibility of Siris NDF in comparison to the alfalfa (Babadi et al. 2017).

\section{Rumen fermentation parameters and protozoa population}

The normal $\mathrm{pH}$ range varies from 6 to 7 , depending on the type of ration. In the present experiment, the rumen $\mathrm{pH}$ was in the optimal range for the activity of microorganisms (Table 3 ). Consistent with the present results, tannin-containing feedstuff sources did not affect ruminal pH (Bhatta et al. 2007). The pH 
may remain constant due to no change in the protozoa population (Table 3) or fatty acid concentration, especially the propionic acid. Contrary to the results of the present experiment, the use of some tannincontaining feeds, including oak (Maldar et al. 2010), olive pomace (Yanez Ruiz et al. 2004), and Siris foliage (Babadi et al. 2018), caused to decrease ruminal pH. Because protozoa have stabilizing properties in the rumen, due to the rapid digestion and storage of starch by ciliated protozoa (Hristov et al. 2001), part of the decrease in $\mathrm{pH}$ has been attributed to a decrease in the rumen protozoa population with the consumption of tannin-containing feed. Perhaps the reason for the difference in their results with the present experiment is the higher concentration of tannin in oak (8 to 10\%) (Maldar et al. 2010) compared to Siris (3.66\%), which did not affect the protozoa population (Table 3).

Decreased rumen protein degradation due to tannin binding to feed protein (Yanez Ruiz et al. 2004) and reduced growth and activity of proteolytic bacteria (Min et al. 2005) resulted in reducing the ammonia nitrogen production in the rumen. Therefore, the tannin in Siris may be the cause of ammonia nitrogen reduction; however its low concentration in the diet does not make a significant difference (Frutos et al. 2002). Protozoa have proteolytic and deamination activities that lead to the production of ammonia in the rumen (Williams and Coleman 1991); Therefore, due to no differences in protozoa populations among experimental treatments (Table 3), the lack of differences in ammonia nitrogen concentration was expected. Agrees to the results of the present experiment, consumption of oak leaves (such as Siris containing tannins) did not cause a significant decrease in ruminal ammonia nitrogen concentration (Yildiz et al. 2005).

The fed $50 \%$ and $75 \%$ of Siris foliage instead of alfalfa to Najdi goat, significantly reduced concentration ammonia nitrogen, and $75 \%$ replacement had the lowest concentration of ammonia nitrogen, which is contrary to the results of the present experiment; however, in the present experiment, a numerical decrease in ammonia nitrogen was observed in diets containing Siris. Compared to alfalfa, feeding Siris foliage to goats significantly decreased ruminal $\mathrm{pH}$, and ammonia nitrogen concentration, due to the presence of tannins in Siris (Babadi et al. 2017). The tannin in Siris protects the feed protein against ruminal degradation, consequently decreasing ammonia nitrogen concentration (Frutos et al. 2002). Disagrees with the results of the present experiment, by replacing the $25,50,75$, and $100 \%$ leaves, flowers, and pods (containing seeds) of Siris instead of alfalfa in sheep diets, the $\mathrm{pH}$ of the culture medium were significantly reduced (Yousefi et al. 2016). However, agreeing to the results of the present experiment, the ammonia nitrogen concentration of treatments with $50 \%$ replacement leaves and pods and both 50 and $75 \%$ levels of flowers was not affected by the replacement of alfalfa by Siris (Yousefi et al. 2016). In contrary to the results of the present experiment, the ammonia nitrogen concentration was significantly reduced, when replacement $75 \%$ of leaves or pods of Siris instead of alfalfa. The probable reason for these differences could be the use of leaves, flowers, and pods separately in their experiment compared to the foliage (leaf, pod, and seed) in the present experiment; because the chemical composition of these components is different from each other and foliage (Babadi et al. 2018; Yousefi et al. 2014 and 2016).

It was shown that using Siris (Babadi et al. 2018) and oak leaves (Maldar et al. 2010) in the ration of goats reduced the population of rumen protozoa. However, in an experiment, feeding goats with oak 
kernel did not affect the population of Protozoa (Hoseinpour-mohammadabadi 2019); this was attributed to the presence of the high amount of starch in the oak kernel because starch, like protein, binds to tannins and reduces its harmful effect. Tannins have an advers effect on proteolytic bacteria, which are a feed for the protozoa (McSweeney et al. 2001). On the other hand, increasing the amount of tannin in ration decreased the ruminal $\mathrm{pH}$ that it can result in a reduction of the protozoa population (Dehority 2003); which is contrary to the results of the present experiment because in the present experiment, the $\mathrm{pH}$ was not affected by tannin of Siris (Table 3 ). One of the reasons for not observing adverse effects for tannins of Siris could be its low amount (3.66\% of Siris dry matter) in the whole diet and no reduction of ruminal pH (Dehority 2003). On the other hand, saponin in Siris $(669.40 \mathrm{mg} / \mathrm{kg}$ compared to $80.27 \mathrm{mg} / \mathrm{kg}$ for alfalfa) may also harm the population of Protozoa (Babadi et al. 2017). The most significant effect of saponin is on the rumen protozoa (Wallace et al. 2002). Saponins cause cell lysis by binding to sterols in the Protozoa membrane. However, because of the lack of this sterol in the bacterial membrane, saponins cannot bind to bacteria. Although many studies have shown a decrease in the population of Protozoa in the presence of saponins, some have shown that its anti-Protozoa effect is unstable and transient, maybe this was a reason for no adverse effects of Siris, which contains saponins (Wallace et al. 2002). On the other hand, the suitable pH for Protozoa in the solid part of the rumen contents is 6.7, which in the present experiment, despite the use of Siris (contains tannins), the $\mathrm{pH}$ was in the appropriate range for their activity (Table 3 ).

\section{Blood metabolites}

It was shown that in comparison with tannin-free diets, feeding diets containing tannins in goats did not affect blood glucose (Merkel et al. 2001), total protein, serum albumin (Ben Salem et al. 2002), cholesterol, and blood urea nitrogen (Babadi et al. 2018), which is consistent with the results of the present experiment. Saponin $(669.40 \mathrm{mg} / \mathrm{kg}$ vs. $80.27 \mathrm{mg} / \mathrm{kg}$ for in Siris and alfalfa, respectively) can affect membrane permeability and reduce blood cholesterol (Hu et al. 2005), which in the present experiment, there has been a numerical reduction; may be due to a low concentration of saponin in the diet (Hu et al. 2005).

In the liver, blood urea nitrogen (BUN) is synthesis from absorbed ruminal ammonia nitrogen so that the concentration of BUN has a positive correlation with the ruminal ammonia nitrogen. Therefore, the lack of change in the BUN is because of no change in ruminal ammonia nitrogen (Hosoda et al. 2005). No change in the concentration of hepatic factors such as aspartate aminotransferase, aspartate transferase, and creatine indicate no damage to the parenchymal tissue of the liver (Al-Shanti et al. 2013).

\section{Feed consumption}

In an experiment, the consumption of Siris was higher than alfalfa (Babadi et al. 2017). Using $50 \%$ and $75 \%$ of Siris foliage instead of alfalfa forage in the diet of Najdi goats caused a linear increase in daily feed consumption (Babadi et al. 2018). It was shown that the use of $15 \%$ of Siris leaves in the sheep diet as a supplement to seasonal dry grasses led to an increase in their consumption (Kennedy et al. 2002). 
This study showed that Siris could be used as a source of nitrogen effectively and economically to improve the use of fiber during the dry season (Kennedy et al. 2002). Supplementation of ammoniated sugarcane bagasse with Siris leaves or wheat bran led to an increase in goat feed intake, which was the most increase in the diet containing Siris leaves (Balgees et al. 2009). Overall, the use of Siris in several experiments increased feed intake, which was used as a supplement to low-quality roughages, which are typically poor in nutrients, especially protein. Perhaps the lack of effect on feed intake in the present experiment is the sufficient nitrogen richness of the diet and the closer similarity of the alfalfa protein concentration with Siris.

\section{Growth performance and Carcass traits}

Animal growth rate and carcass traits depend on feed intake and dietary nutrient availability, and the efficiency of lambs in converting feed to live weight and depends on various factors such as breed, sex, age, and nutritional levels (Thompson et al. 1987). Therefore, considering the level of feed consumption, the same nutrition, and race, age, and sex, the un-significant differences in most characteristics between treatments were reasonable and expected. Due to the higher price of alfalfa forage and its need for suitable land, abundant water, and special reserving conditions, no difference in growth performance and carcass traits in diets containing Siris compared to alfalfa forage is one of the important and valuable results of the present experiment; because the Siris that is found in abundance in parts of the world can be used without adversely affecting the performance of fattening lambs.

\section{Meat colour}

Color is a visual property of meat and carcasses that is known as the first effective criterion in the selection and evaluation of meat and carcasses (Suman et al. 2014). Studies have shown that the consumer preference in European countries for red mutton is $a^{*}<9.5$, which this index in the current experiment is in the same range and is the lowest even in $75 \%$ replacement treatment. The most important compounds that cause color in meat are pigments that absorb some wavelengths of light and reflect other light. Muscle structure and texture also affect the amount of light absorbed and reflected. Meat pigments include hemoglobin or blood pigment proteins, myoglobin or muscle pigment (80-90\% of meat color), and catalase and cytochrome enzymes that have a negligible effect on meat color (Apaoblaza et al. 2015). A higher index in the yellowness may be partly related to the storage of more fat within the muscle. Differences in fat content can cause differences in meat color (De Backer and Hudders 2015). It seems that these factors in the present experiment did not affect the tendency of redness and yellowing of the meat.

\section{Conclusion}

The results of the present experiment were shown the use of the Siris foliage in the diet of fattening lambs as a substitute with part of alfalfa not only did not hurt digestion, fattening performance, ruminal and blood parameters, but also in some cases improved them. Due to the high price of alfalfa forage and its need for suitable land, abundant water, and special reservation conditions, no difference in the results 
of treatments is a valuable and positive achievement for the present experiment. Therefore, according to the results of the present experiment, the nutritional value of Siris foliage is comparable to alfalfa forage, and it can be used in the diet of ruminants. It is recommended that Siris nutritional value be studied as an alternative to alfalfa in other ruminants, especially dairy livestock and their offspring such as lambs, goat kids, and suckling calves, male and female calves, or heifers.

\section{Declarations}

Acknowledgment The Agricultural Sciences and Natural Resources University of Khuzestan supported this study. The authors would like to thank for all supports.

Funding information: This work was financially supported by Agricultural Sciences and Natural Resources University of Khuzestan.

Ethical approval The manuscript does not contain clinical studies or patient data.

Conflict of interest The authors declare that they have no conflict of interest.

Availability of data and material (data transparency): The datasets generated during and/or analysed during the current study are available from the corresponding author on reasonable request.

Authors' contributions: $\mathrm{M}$ conceived and designed research. $\mathrm{M}, \mathrm{H}$, and $\mathrm{O}$ conducted experiments. $\mathrm{M}$ and $\mathrm{H}$ analyzed data. $\mathrm{M}$ and $\mathrm{H}$ wrote the manuscript. All authors read and approved the manuscript.

\section{References}

1. Al-Shanti,H.A., Kholif,AM., Al-Shakhrit,K.J., AL-Banna, M.F., Abu Showayb, I.E., 2013. Use of crushed date seeds in feeding growing Assaf lambs. Egypt Journal of Sheep and Goat Sience, 8 (1), 1-19. https://www.cabdirect.org/cabdirect/abstract/20133139422.

2. AMSA, 2012. Meat color measurement guidelines. Champaign, IL, USA: American Meat Science Association.

3. AOAC International. 2012. Official Methods of Analysis. $19^{\text {th }}$ ed. Gaithersburg, MD: Association of Official Analytical Chemists International.

4. Apaoblaza, A., Galaz, A., Strobel, P., Ramírez-Reveco, A., Jeréz-Timaure, N., Gallo, C., 2015. Glycolytic potential and activity of adenosine monophosphate kinase (AMPK), glycogen phosphorylase (GP) and glycogen debranching enzyme (GDE) in steer carcasses with normal $(<5.8)$ or high $(>5.9) 24 \mathrm{H}$ pH determined in M. Iongissimus dorsi. Meat science, 101, 83-9.10.1016/j.meatsci.2014.11.008.

5. Babadi, L., Chaji, M.,Mohammadabadi, T., 2017. Comparison digestibility, rumen fermentation and protozoa population in najdi goats fed with whole branch of Albizia or alfalfa hay. Iranin Journal of Animal Science Research, 9(1), 13-23.10.22067/IJASR.V9I1.52162. 
6. Babadi, L., Chaji, M.,Mohammadabadi, T., 2018. The effect of feeding whole branch of Albizialebbeck tree on digestibility, some fermentation characteristics and rumen protozoa population of Najdi goats. Animal Science Research, 28(1), 195-

211.https://animalscience.tabrizu.ac.ir/article_7583.html?lang=en.

7. Balgees, A., Elmnan, A., Elseed, A.M.A.F.,Salih, AM., 2009. Effects of Albizialebbeck or wheat bran supplementation on intake, digestibility and rumen fermentation of ammoniated bagasse. Journal of Applied Scienes Research, 5(8), 1002-1006.

8. Ben Salem, H., Atti, N., Priolo, A.,Nefzaoui, A., 2002. Polyethylene glycol in concentrate or feed blocks to deactivate condensed tannins in Acacia cyanophyllaLindl foliage. 1. Effects on intake, digestion and growth by Barbarine lambs. Journal of Animal Science, 75, 127135.https://doi.org/10.1017/S1357729800052905.

9. Bhatta, R., Shinde, A.K.,Verma, D.L., Sankhyan, S.K.,Vaithiyanathan, S., 2007. Effect of supplementation containing polyethylene glycol (PEG)-6000 on intake, rumen fermentation pattern and growth in kids fed foliage of Prosopis cineraria. Small Rumin Research, 52, 45-52. 10.1016/S0921-4488(03)00222-0.

10. Brodrick, G.A., Kang, J.H., 1980. Automated simultaneous determination of ammonia and total amino acids in ruminal fluid and in vitro media. Journal of Dairy Science, 63, 6475.https://doi.org/10.3168/jds.S0022-0302(80)82888-8.

11. De Backer, C.J.S.,Hudders, L., 2015. Meat morals: relationship between meat consumption consumer attitudes towards human and animal welfare and moral behavior.Meat Science, 99, 6874.https://doi.org/10.1016/j.meatsci.2014.08.011

12. Dehority, B.A., 2003.Rumen Microbiology.Nottingham University Press, Nottingham, UK

13. El-Hawary, S., El-Fouly, K.E., Sokkar, N.M., Talaat, Z., 2011. A phytochemical profile of Albizialebbeck (L.) benth, cultivated in Egypt. Asian Journal of Biochemistry, 6 (2), 122-141. 10.3923/ajb.2011.122.141.

14. Eynipour, P., Chaji, M., Sari, M., 2019. Use of post-harvest common bean (Phaseolus vulgaris L.) residues in diet of lambs and its effect on finishing performance, rumen fermentation, protozoa population and meat characteristics.Journal of animal physiology and animal nutrition,103(6), 17081718. https://doi.org/10.1111/jpn.13192.

15. FASS, 2010. Guide for the Care and Use of Agricultural Animals in Research and Teaching, 3rd ed. Champaign, IL: Federation of Animal Science Societies. https://www.aaalac.org/about/ Ag_Guide_3rd_ed.pdf

16. Fisher, A.V., de Boer, H., 1994. The EAAP standard method of sheep carcass assessment. Carcass measurements and dissection procedures report of the EAAP working group on carcass evaluation, incooperation with the CIHEAM InstitutoAgronomicoMediterraneo of Zaragoza and the CEC Directorate General for Agriculture in Brussels. Livestock Production Science, 38, 149-159. https ://doi. org/10.1016/0301-6226(94)90166-X. 
17. Frutos, P., Hervás, G., Ramos, G., Giráldez, F.J.,Mantecón, A.R., 2002. Condensed tannin content of several shrubspecies from a mountain area in northern Spain, and its relationship to various indicators of nutritive value. Animal Feed ScienceTechnolology, 95, 215-226. 10.1016/S03778401(01)00323-6.

18. Hassan, L.G., Umar, K.J., Atiku, I., 2007. Nutritional Evaluation of Albizialebbeck (L.) Pods as source of feeds for livestock. American Journal of Food Technology, 2, 435-439.10.3923/ajft.2007.435.439.

19. Hoseinpour-mohammadabadi, H.,Chaji, M., 2019. Effect of oak kernel on digestibility, growth performance, protozoa population and ruminal and blood parameters of fattening goat kids. Iranian Journal of Veterinary Medicine, 15(2): 38-49.10.22055/IVJ.2018.110835.1998.

20. Hosoda, K., Nishida, T., Park, W.Y.,Eurden, B., 2005. Influence of Menthapiperita L. (peppermint) supplementation on nutrient digestibility and energy metabolism in lactating dairy cows. AsianAustralasian Journal of Animal Sciences, 18, 1721-1726. https://doi.org/10.5713/ajas.2005.1721.

21. Hristov, A.N., Ivan, M., Rode, L.M., Mc Allister, T.A., 2001. Fermentation characteristics and rumen ciliate protozoal populations in cattle fed medium or high barleybased diets. Journal of Animal Science, 79(2), 515-524.10.2527/2001.792515x.

22. Hu, W.L., Liu, J.X., Ye, J.A., Wu, Y.M.,Guo, Y.Q. 2005. Effect of tea saponin on rumen fermentation in vitro. Animal Feed Scienceand Technology, 120 (3-4), 333-

339.https://doi.org/10.1016/j.anifeedsci.2005.02.029.

23. Jones, G.A., McAllister, T.A., Muir, A.D., Cheng, K.J., 1994. Effects of sainfoin (OnobrychisviciifoliaScop.) condensed tannins on growth and proteolysis by four strains of ruminal bacteria. Applied and environmental microbiology, 60(4), 1374-

1378.https://www.ncbi.nlm.nih.gov/pmc/articles/PMC201486/

24. Kennedy, P.M., Lowry, J.B., Coates, D.B., Oerlemans, J., 2002. Utilisation of tropical dry season grass by ruminants is increased by feeding fallen leaf of siris (Albizialebbeck). Animal Feed Science and Technology, 96(3-4), 175-192.

25. Maldar, S.M., Roozbehan, Y.,Alipour, D., 2010. The effect of adaptation to oak leaves on digestibility (in vitro) and ruminal parameters in Alamout goat. Iranian Journal of Animal Science, 41(3), 243-252. https://ijas.ut.ac.ir/article_22089.html?lang=en.

26. McSweeney, C.S., Palmer, B., McNeill, D.M., Krause, D.O., 2001. Microbial interactions with tannins: nutritional consequences for ruminants. Animal Feed Science and Technology, 91, 8393.https://doi.org/10.1016/S0377-8401(01)00232-2.

27. Merkel, R.C., Toerien, C., Sahlu, T., Blanche, C., 2001. Digestibility, N balance and blood metabolite levels in Alpine goat wethers fed either water oak or shining sumac leaves. Small Ruminant Research, 40(2), 123-127. 10.1016/s0921-4488(00)00220-0.

28. Min, B.R., Attwood, G.T., McNabbb, W.C., Molanb, A.L., Barry, T.N., 2005. The effect of condensed tannins from Lotus corniculatus on the proteolytic activities and growth of rumen bacteria. Animal Feed Science and Technology, 121, 45-58. 10.1016/j.anifeedsci.2005.02.007.

29. Mozafarian, V. 2005. Trees and shrubs in Iran. First ed. Fahangmoaser, Tehran, Iran. 
30. NRC. 2007. Nutrient requirements of small ruminants, sheep, goats, cervids, and camelids. Washington, DC:National Academy of Science, P: 384.

31. Patra, A.K., Sharma, K., Narayan, D.,Pattanik, A.K., 2003. Reponse of gravid dose to partial replacement of dietary protein by a leaf meal mixture of Leucaenaleucocephala, Morusalba and Azadirachiaindica. Animal Feed Science and Technology, 109, 171182.https://doi.org/10.1016/S0377-8401(03)00202-5.

32. Rashid, R.B., Chowdhury, R., Jabbar, A., Hasan, C.M., Rashid, M.A., 2003. Constituents of Albizzialebbeck and antibacterial activity of onisolated flavone derivative. Saudi Pharmaceutical Journal, 11, 52-55.

33. Samtiya, M., Aluko, R.E., Dhewa, T., 2020 Plant food anti-nutritional factors and their reduction strategies: an overview. Food Production, Processing and Nutrition 2 (6), 1-14. https://doi.org/10.1186/s43014-020-0020-5

34. Shahriari, Z.,Mohammadabadi, T.,Tabatabaei-Vakili, S.,Chaji, M., Sari, M., 2017. Effect of replacing alfalfa with subabul (Leucaenaleucocephala) pod on digestibility, in vitro fermentation and in situ degradability in cow and buffalo. Animal Production Research, 6 (3): 63-72.10.22124/AR.2017.2366.

35. Suman, S.P., Hunt, M.C., Nair, M.N., Rentfrow, G., 2014. Improving beef color stability: Practical strategies and underlying mechanisms. Meat Science, 98, 490-504. 10.1016/j.meatsci.2014.06.032

36. Thompson, J.M., Butterfield, R.M.,Perry, D.,1987. Food intake, growth and body composition in Australin Merino Sheep selected for high and low weaning weight. 4. Partitioning of dissected and chemical fat in the body. Animal Science , 45 (1), $49-60$. https://doi.org/10.1017/S0003356100036618.

37. Van Soest, P.J., Roberson, J.B., Lewis, B.A., 1991. Methods of dietary fiber, neutral detergent fiber, and non-starch polysaccharides in relation to animal nutrition. Journal of Dairy Science, 74(10), 35833597.https://doi.org/10.3168/jds.S0022-0302(91)78551-2.

38. Wallace, R.J., McEwan, N.R., McIntosh, F.M., Teferedegne, B., Newbold, C.J., 2002. Natural products as manipulators of rumen fermentation. Asian-Australasian Journal of Animal Sciences, 15: 14581468.https://doi.org/10.5713/ajas.2002.1458.

39. Williams, A. G. and Coleman, G. S. 1991. The Rumen Protozoa. Springer Verlag,Inc. New York, NY, USA. Pp. 441.

40. Yanez Ruiz, D.R., Moumen, A., Martin Garcia, A.I., Molina Alcaide, E., 2004. Ruminal fermentation and degradation patterns, protozoa population, and urinary purine derivatives excretion in goats and wethers fed diets based on two-stage olive cake: effect of PEG supply. Journal of Animal Science, 82, 2023-2032. 10.2527/2004.8272023x.

41. Yildiz, S., Kaya, I., Unal, Y., AksuElmali, D., Kaya, S., Cenesiz, M., Kaya, M.,Oncuer, A., 2005. Digestion and body weight change in Tuj lambs receiving oak (Quercushartwissiana) leaves with and without PEG. Animal Feed Science and Technology, 122, 159-172. http://dx.doi.org/10.1016/j.anifeedsci.2005.04.005. 
42. Yousefi, Z.,Mohammadabadi, T.,Chaji, M.,Bojarpour, M., 2014. Investigation of in vitro digestibility and fermentation of diets containing of diferent parts of Siris (Albizialebbeck). Animal production, 16, 31-41.10.22059/JAP.2014.52228.

43. Yousefi, Z., Mohammadabadi, T., Chaji, M., Bojarpour, M., 2014. Investigation of in vitro digestibility and fermentation of diets containing of diferent parts of Siris (Albizialebbeck). Animal Science Research, 26 (4), 19-32.https://animalscience.tabrizu.ac.ir/article_6094.html?lang=en. 